\title{
Two endemic viverrids of the Western Ghats, India
}

\author{
N. V. K. Ashraf, A. Kumar and A. J. T. Johnsingh
}

The Malabar and brown palm civets, Viverra civettina and Paradoxurus jerdoni, are both endemic to the Western Ghats of south-west India. Little is known about them and in 1990 a survey was conducted in three parts of the Western Ghats to assess their status. This revealed that isolated populations of Malabar civet still survive in less disturbed areas of South Malabar but they are seriously threatened by habitat destruction and hunting because they are outside protected areas. The brown palm civet is not immediately threatened because there are about 25 protected areas within its distribution range. Recommendations have been made for conservation action to ensure the survival of these animals.

\section{Introduction}

Two of the seven species of civets in India, the Malabar civet Viverra civettina and the brown palm civet Paradoxurus jerdoni, are endemic, being confined to the Western Ghats of southwest India (Figure 1). These are the only two Indian viverrids described as priority species for conservation by the Mustelid and Viverrid Specialist Group (M\&VSG) of the IUCN/SSC (Schreiber et al., 1989). Despite their rarity, they have received little scientific or conservation attention. A 3-month preliminary survey of these two species was conducted from April to June 1990. This was organized by the Wildlife Institute of India, under the initiative of M\&VSG with funding from the Zoological Society for the Conservation of Species and Populations, Germany.

\section{Malabar civet}

The Malabar civet is one of four viverrids listed as endangered in the 1990 IUCN Red List of Threatened Animals (Thornback et al., 1990). The species was not recorded during surveys conducted by the Zoological Society of London and by the British Museum (Natural History) in the early part of this century (Kurup, 1989). Hutton (1949), however, reported this species from the High Wavy
Mountains, Madurai, Tamil Nadu. In the last 40 years, there have been only two possible sightings, one in Kudremukh in Karnataka (Karanth, 1986) and the other in Tiruvella in Kerala (Kurup, 1989). Listed as 'possibly extinct' in the IUCN Mammal Red Data Book of 1978 (Thornback, 1978), the species was rediscovered in Elayur, a locality in the lowland Western Ghats, in Malappuram district, Kerala (Kurup, 1989).

The current distribution of the Malabar civet is not clearly understood. Most published reports suggest that it is largely a species of lowland tracts of the Western Ghats (Jerdon, 1874; Pocock, 1939; Prater, 1948). It has also been reported from the elevated tracts of Wynad, Coorg (Jerdon, 1874) and High Wavy Mountains of Western Ghats (Hutton, 1949).

\section{Brown palm civet}

The brown palm civet was sighted by $A$. Kumar in 1983 and 1990, and by Chandrasekar (1989) in Indira Gandhi Wildlife Sanctuary (previously Anaimalai Wildlife Sanctuary) of Tamil Nadu, and also by E. R. C. Davidar (in Schreiber et al., 1989) in Coonoor, Tamil Nadu. Because these sightings and most of the museum specimens were from the elevated moist forests of the Western Ghats, it probably 


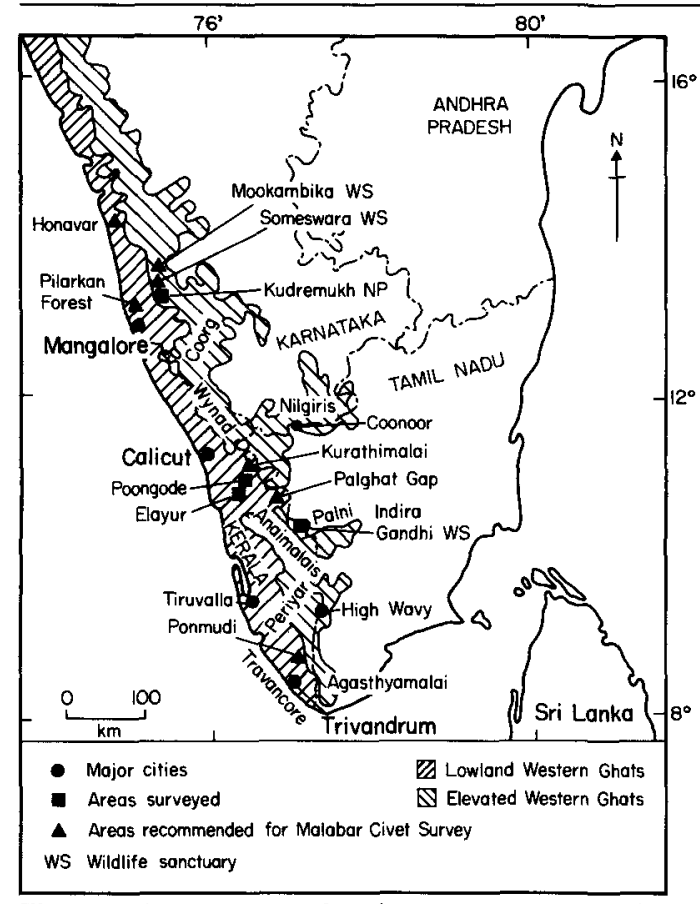

Figure 1. Areas surveyed and areas recommended for further survey in parts of south-west India.

occurs in other protected areas as well. Two subspecies of brown palm civet are recognized, the southern $P . j$. jerdoni and the northern P.j.caniscus.

Unlike the Malabar civet, most museum specimens of brown palm civet were collected from moist forests above $500 \mathrm{~m}$ altitude. While the rarer P. j. caniscus is known from North and South Coorg hills, the better known $P$. $j$. jerdoni is reported from the southern parts of Western Ghats, namely Nilgiris, Anaimalais, Palni and also Travancore (Pocock, 1939). Recent records of this species from Coonoor (in Nilgiris) and Indira Gandhi Wildlife Sanctuary (in Anaimalais) further suggest that it inhabits the elevated mountain Ghats. The species has not been reported in recent years from the lowland tracts of Malabar and Travancore.

The aims of the preliminary survey were:

1. to assess the status and conservation needs of Malabar and brown palm civets in selected areas in their distribution range;

2. to gather information on their ecology and habitat preferences and;
3. to assess the feasibility of long-term ecological studies on these species.

\section{Survey areas and methods}

The selection of survey areas was based on recent reports of sightings and captures of Malabar and brown palm civets. The precise collection locality is known for only two out of about 11 museum specimens of Malabar civet. Both were obtained in 1987 from Elayur, Kerala (South Malabar). Elayur and adjoining areas of Calicut and Palghat districts of Kerala were, therefore, selected for the survey (Figure 1).

The only two recent sightings of Malabar civet are from Kudremukh in Karnataka (Karanth, 1986) and Tiruvella in Kerala (Kurup, 1989). The former (600 sq km) was selected because it is the only protected area from which this animal has been reported. Moreover, it falls within the distribution range of the northern subspecies of the brown palm civet $P$. j. caniscus. Another area selected for brown palm civet was Indira Gandhi Wildlife Sanctuary (987 sq km).

Methods included interviews with Forest Department staff, tribal people, native hunters, Ayurvedic physicians, civet rearers and trappers. Brochures with pictures of Malabar civet, small Indian civet Viverricula indica, and common palm civet Paradoxurus hermaphroditus were distributed in the Malabar civet survey areas. Other methods included night transects and watch-tower observations using a spotlight. There are few motorable roads, which restricted the use of vehicle for transects. Attempts were made to sample all vegetation types, but where there had been recent sightings these were more intensively surveyed. Information was also gathered on habitat preferences of the species. For watch-tower observations, small wooden platforms were erected as vantage points for overnight observations, near fruiting trees, natural water points, deep gorges or tunnels. This method was used most in Indira Gandhi Wildlife Sanctuary for sighting the brown palm civet. 
Figure 2. A general profile of plantation types in South Malabar where isolated populations of Malabar civet survive.

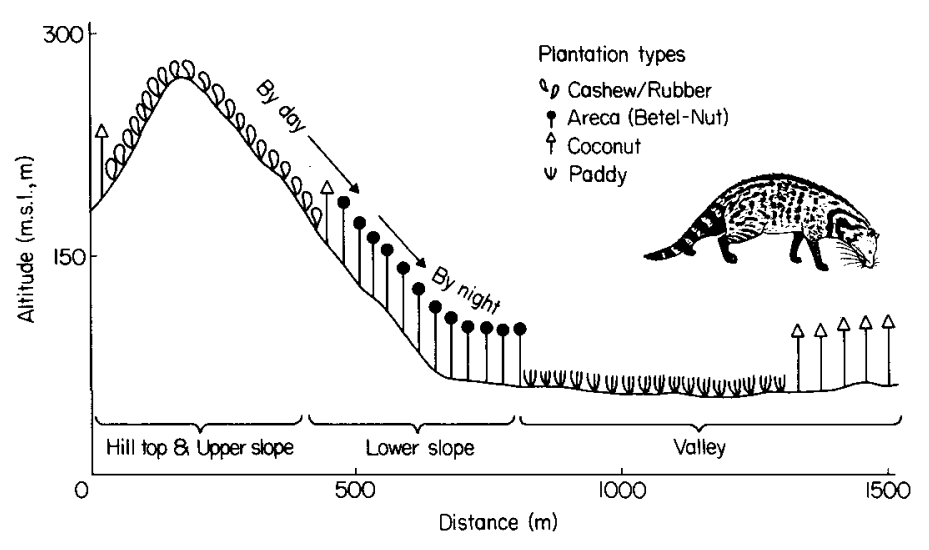

\section{Results and discussion}

The survey for the Malabar civet covered about $105 \mathrm{~km}$, mostly on foot, in 84 hours in different plantation types in Elayur and the nearby village of Poongode. The exact distance covered in each vegetation type was difficult to estimate because of the complicated mosaic of plantation types. However, most time was spent in cashew plantations and along the edges of slopes and riparian borders of valleys. At Kudremukh National Park, little field-work could be carried out because of torrential rain.

For the brown palm civet, about $170 \mathrm{~km}$ was covered in tropical evergreen forest, moist deciduous forest and plantations in 34 nighthours of vehicle transect in Indira Gandhi Wildlife Sanctuary. Foot transects covered a distance of $35 \mathrm{~km}$ in evergreen forests in about 11 hours. Watch-tower observations lasted 64 hours during 9 nights. Almost all the observation points were near fruiting trees.

\section{Malabar civet}

Although no Malabar civets were seen, evidence of their existence was found in parts of South Malabar: skins of two animals captured in 1987 and 1990 were found in Poongode and a defecation site (civetry) was discovered in Elayur.

Scarcely anybody in the survey areas recognized the Malabar civet as a critically endangered species. About 90 per cent of over people interviewed were not even aware of the existence of the species. The local name for the species, jawad, is popular among the remaining 10 per cent, who are mainly hunters, trappers, Ayurvedic physicians and civet rearers. None of the six hunters interviewed in Kudremukh National Park recognized the Malabar civet.

Out of 22 areas surveyed, seven had had one or more captive Malabar civets sometime during the past 30 years for collecting 'civetmusk'. While musk is collected from the small Indian civet without restraining the animal, musk is obtained from the Malabar civet by special manipulation. The civet-musk of the Malabar civet is said to have been in widespread use $20-25$ years ago.

Ecology. Natural forests have completely disappeared in the entire stretch of the coastal Western Ghats due to early colonization by man. The present vegetation is, therefore, of secondary origin (Champion and Seth, 1968), and consists mostly of plantations. These plantations follow a pattern according to the terrain and presence of riparian areas. Cashew, rubber and sometimes coconut plantations are found on the drier hill tops and upper slopes, while the lower moist slopes are planted with betel-nut palms. The valleys are dominated by paddy fields and sometimes coconut (Figure 2). Of these, the cashew plantations are the least disturbed. They are not weeded and so have a dense understorey of shrubs and grasses. For a terrestrial species such as the 
Table 1. Localities in Malappuram district of Kerala where Malabar civets could be captured for a captivebreeding programme

\begin{tabular}{|c|c|c|c|c|}
\hline No. & Place & Post office & Nearest town & Reason for selection \\
\hline 1 & Poongode & Vellayur & Wandoor & Two animals captured March 1990 \\
\hline 2 & Chembrakkattur & Kadungallur & Areacode & $\begin{array}{l}\text { Individuals have been trapped often, } \\
\text { most recent in } 1989\end{array}$ \\
\hline 3 & Chattangotupuram & Chattangotupuram & Wandoor & Trapped in 1988, recent sightings \\
\hline 4 & Elayur & Iruvetty & Areacode & Three animals captured, 1987 \\
\hline 5 & Kilinakod & Cherur & Vengara & $\begin{array}{l}\text { Captured in } 1976 \text { and } 1984 \text { and recent } \\
\text { sightings in Uragam, Arimbara hills }\end{array}$ \\
\hline 6 & Arimbara & Arimbara & Kondotty & $\begin{array}{l}\text { Captured in } 1976 \text { and } 1984 \text { and recent } \\
\text { sightings in Uragam, Arimbara hills }\end{array}$ \\
\hline 7 & \multicolumn{3}{|c|}{ Calicut University campus } & N. G. George pers. comm. \\
\hline
\end{tabular}

Malabar civet, these thickets provide important cover. It is probable that the cashew plantations are a 'refuge' rather than a preferred habitat. Most captures of this species in the last 30 years, however, have been in the valleys, around riparian areas. This suggests their possible dependence on shallow water courses where they forage at night (Figure 2).

The Malabar civet has never been observed in trees and possibly forages almost entirely on the ground. Like the African civet and other large civets (Wemmer, 1984), they are also known to have specific defecation sites. Considered aggressive among conspecifics, they have been observed usually alone. Evidence suggests that the young are raised in secluded thickets.

Threats. Increasing human disturbance, habitat destruction and fragmentation, poaching and trapping are the major threats facing this species. Cashew plantations, which probably hold most of the surviving populations of Malabar civet, are now threatened by largescale clearance for planting rubber. Moreover, the closed canopy of a mature rubber plantation prevents the growth of shrubs and grasses, which are essential cover for this species. The Malabar civet, a Schedule I species under the Indian Wildlife Protection Act 1972, is not selectively hunted but is captured and killed when encountered. Out of 22 Malabar civets reported captured on 18 occasions in the last 40 years, 10 were caught by dogs. Dogs are reported to become excited by the Malabar civet's scent and easily provoked by the civet's fierce response to interference.

\section{Brown palm civet}

No evidence of brown palm civet could be found during the survey at Anaimalais. Reports that it is hunted outside Kudremukh National Park suggest that it is present in this protected area. Local people had little knowledge about the brown palm civet, perhaps because it is nocturnal and probably largely arboreal, and might have gone unnoticed by the local villagers who rarely venture into the forests at night.

Ecology. Little is known about the ecology of brown palm civet. The three recent sightings of this species in Anaimalais were in evergreen forests. Coonoor, where Davidar trapped a specimen in 1976 (Schreiber et al., 1989) also had some patches of evergreen forest in the past. The adjoining Mudumalai 
Wildlife Sanctuary has no evergreen forests and is unlikely to contain the species. Further surveys and studies are essential to determine whether or not this species is dependent on evergreen forests.

The brown palm civet is most likely to occur in low densities, especially compared with the common palm civet. Both these arboreal species have been reported from evergreen forests in the same localities (for example Kudremukh). But unlike the brown palm civet, the common palm civet is frequently sighted even beyond the limits of coffee and tea plantations. Adaptability to habitat disturbance is probably the major difference between these two species. Hutton (1949), suggested that they mated around May, basing this on the fact that they were heard to call at this time.

Threats. This species may be more elusive than the Malabar civet because of its arboreal habits and its occurrence in moist forests. Many of the protected areas in the Western Ghats are threatened by development programmes. Mining activities in Kudremukh, hydroelectric projects in Anaimalais and large-scale plantations of coffee, cardamom and tea in and around these protected areas have vastly depleted the forest cover. Hunting is unlikely to be a major threat to the survival of brown palm civet. However, illegal hunting is still common in privately owned coffee, cardamom and tea estates.

\section{Conclusions}

Isolated populations of Malabar civet still survive in less disturbed thickets on small hills and gentle slopes in South Malabar, Kerala. However, even these surviving populations are seriously threatened. It has vanished recently from most of its past range due to habitat destruction and hunting. The lowland Western Ghats have no protected areas or any extensive areas of undisturbed natural vegetation that could be protected for the conservation of this species. The brown palm civet has been reported from elevated tracts of
Western Ghats where there are about 25 protected areas in its distribution range. This species is not immediately threatened, but various development activities might threaten its survival in future.

\section{Recommendations}

The following recommendations are made for conservation action to ensure the survival of these viverrids.

\section{Captive breeding}

Reports of frequent captures of Malabar civet in recent years in many localities show that these isolated populations are under tremendous pressure. The designation of protected areas is not feasible in these densely populated areas and we cannot assume that the species would be represented in any protected area of the Western Ghat mountains, where it has not been definitely recorded. It is, therefore, strongly recommended that a few individuals be captured for a captive-breeding programme. This could be done in areas where the species is under severe hunting pressure and where it is impossible to implement long-term conservation measures (Table 1). Reintroduction could be possible if suitable undisturbed areas were identified.

\section{Field surveys}

Intensive surveys in some key areas of both the elevated and coastal provinces of Western Ghats are recommended.

The suggested Kurathimalai and Ponmudi Sanctuaries in Kerala, and Honavar riverine fragments and Pilarkan forest in Karnataka have some undisturbed lowland forests (Rodgers and Panwar, 1988). The Palghat Gap in Kerala and the existing Someswara and Mookambika wildlife sanctuaries in Karnataka also have some lowland forests. Intensive surveys for the Malabar civet in these seven areas (Figure 1) are also recommended.

Surveys in one or two protected areas in each of the six conservation units of the high- 
altitude tracts of Western Ghats (Coorg, Wynad, Nilgiris, Anaimalais, Periyar and Agasthyamalai) are essential to investigate whether the Malabar civet survives in any protected areas. Surveys using live-traps and camera-traps would help to describe the geographical variation of brown palm civet and to assess the relative abundance of common and brown palm civets and the rare Nilgiri marten Martes gwatkinsi.

\section{Ecological studies}

Assessments of humán disturbance, of the effect of pesticides and infectious diseases on isolated populations of Malabar civet in Kerala are required in order to draw up longterm conservation measures. Elaborate ecological studies are possible only if individuals are radio-collared. As far as the brown palm civet is concerned, factors limiting its population size and reasons for its rarity would be of interest. The Malappuram district of Kerala and Indira Gandhi Wildlife Sanctuary of Tamil Nadu are suggested here as key areas for studying Malabar and brown palm civets, respectively. However, better study areas may be identified from the long-term survey suggested above.

\section{Acknowledgments}

This survey was the outcome of interest shown by Roland Wirth, chairman of the M\&VSG, and funding by the Zoological Society for the Conservation of Species and Populations, Germany. We are thankful to the Chief Wildlife Wardens of Kerala, Tamil Nadu and Karnataka for permission to conduct the survey. We are grateful to the director, Wildlife Institute of India, for facilitating the study. Dr G. U. Kurup of Zoological Survey of India, Calicut and $\mathrm{Mr}$ N. G. George of Calicut University provided valuable information on the elusive Malabar civet.

\section{References}

Champion, H.G. and Seth S.K. 1968. Forest types of India. Manager of Publications, Delhi.

Chandrasekar, A. 1989. Ecology of Small Mammals in Tropical Forests of South India. M.Sc. Thesis. Department of Wildlife and Range Sciences. University of Florida, USA.

Hutton, A.F. 1949. Notes on Mammals of High Wavy Mountains, Madurai, South India. Part-II. J. Bomb. Nat. Hist. Soc. 48, 681-694.

Jerdon, T.C. 1874. A Handbook of the Mammals of India. Reprinted in 1984 by Mittal Publications, Delhi.

Karanth K.U. 1986. A possible sighting record of Malabar civet (Viverra megaspila Blyth) from Karnataka. J. Bomb. Nat. Hist. Soc. 83, 192-193.

Kurup G.U. 1989. The rediscovery of the Malabar civet, (Viverra megaspila civettina Blyth) in India. Tiger Paper, 16, 13-14.

Pocock R.I. 1939. The Fauna of British India: Mammals Vol.1. Reprinted in 1975. Today and Tomorrow's Printers and Publishers, New Delhi.

Prater S.H. 1948. The Book of Indian Animals. Reprinted in 1980. Bombay Natural History Society, India.

Rodgers, W.A. and Panwar, H.S. 1988. Planning $A$ Wildlife Protected Area Network in India. Wildlife Institute of India.

Schreiber A., Wirth R., Riffel, M. and Van Rompaey, H. 1989. An Action Plan for the Conservation of Mustelids and Viverrids. IUCN, Gland, Switzerland.

Thornback, J. 1978. Red Data Book, Vol. 1-Mammalia. IUCN, Gland, Switzerland.

Thornback, J., Allan C. and Almada-Villela, P. 1990. IUCN Red List of Threatened Animals. IUCN, Gland, Switzerland, and Cambridge, UK.

Wemmer, C. 1984. Civets and Genets. In The Encyclopedia of Mammals: 1 (ed. David Macdonald), pp. 136-145, George Allen and Unwin, London.

N. V. K. Ashraf, A. Kumar, and A. J. T. Johnsingh, Wildlife Institute of India, Dehra Dun, India 248006. 